\title{
Calcification of the transverse ligament of the atlas in chondrocalcinosis: computed tomography study
}

Department of
Rheumatology,
Centre Hospitalier
Général,
Auch, France
A Constantin
F Marin
E Bon
M Fedele
G Bouteiller
Department of
Radiology
B Lagarrigue
Correspondence to:
Dr G Bouteiller,
Service de Rhumatologie,
Centre Hospitalier Général,
route de Tarbes, BP 382,
32 008 Auch Cedex,
France.
Accepted for publication
3 October 1995

\author{
A Constantin, F Marin, E Bon, M Fedele, B Lagarrigue, G Bouteiller
}

an increased erythrocyte sedimentation rate, sometimes revealing AC.

(Ann Rheum Dis 1996; 55: 137-139)

Attacks of acute neck pain with segmentary stiffness, fever, and a biological inflammatory syndrome, simulating meningitis, are classical symptoms of the axial manifestations of articular chondrocalcinosis. ${ }^{1-3}$ Plain radiographs of the cervical spine are usually disappointing, rarely showing calcification of the atlantoaxial region or intervertebral discs, ${ }^{2}$ and very few publications report calcification of the transverse ligament of the atlas (TLA), as revealed by computed tomography..$^{3-5}$ The present study sought to establish an association between articular chondrocalcinosis and calcification of the TLA, and to assess the frequency and main computed tomography appearances of these calcifications.

\section{Patients and methods}

PATIENTS

We studied 21 patients ( 18 women and three men: mean age 78.9 (SD 5.9) years (range 69-87)) admitted to hospital in the rheumatology department with articular chondrocalcinosis (table). Eight patients had definite articular chondrocalcinosis according to the criteria of McCarty (typical radiological chondrocalcinosis involving more than one set of peripheral joints, and typical calcium

Demographic, clinical and radiological data of the articular chondrocalcinosis group

\begin{tabular}{|c|c|c|c|c|c|c|c|}
\hline $\begin{array}{l}\text { Patient } \\
\text { No }\end{array}$ & $\begin{array}{l}\text { Age } \\
(y r)\end{array}$ & Sex & Reason for admission & $\begin{array}{l}\text { Acute neck pain } \\
\text { history? }\end{array}$ & $\begin{array}{l}\text { Pyrophosphate } \\
\text { crystal in } \\
\text { synovial fluid }\end{array}$ & $\begin{array}{l}\text { Calcification of } \\
\text { knees, wrists, } \\
\text { hips, on } \\
\text { radiographs }\end{array}$ & $\begin{array}{l}\text { Calcification of } \\
\text { TLA on } C T \text { scanst }\end{array}$ \\
\hline $\begin{array}{r}1 \\
2 \\
3 \\
4 \\
5 \\
6 \\
7 \\
8 \\
9 \\
10 \\
11 \\
12 \\
13 \\
14 \\
15 \\
16 \\
17 \\
18 \\
19 \\
20 \\
21\end{array}$ & $\begin{array}{l}81 \\
87 \\
81 \\
73 \\
79 \\
79 \\
77 \\
83 \\
84 \\
84 \\
74 \\
86 \\
81 \\
74 \\
85 \\
69 \\
73 \\
86 \\
69 \\
75 \\
73\end{array}$ & $\begin{array}{l}F \\
F \\
F \\
F \\
F \\
F \\
F \\
F \\
F \\
F \\
F \\
\text { F } \\
\text { F } \\
M \\
M \\
F \\
F \\
F \\
F\end{array}$ & $\begin{array}{l}\text { Degenerative arthropathy: K } \\
\text { Degenerative arthropathy: K } \\
\text { Degenerative arthropathy: K } \\
\text { Pseudogout: K } \\
\text { Degenerative arthropathy: K, H } \\
\text { Degenerative arthropathy: K } \\
\text { Pseudogout: K } \\
\text { Pseudopolyarthritis: K, W, A } \\
\text { Pseudogout: K } \\
\text { Pseudogout: W } \\
\text { Pseudopolyarthritis: K, H, S } \\
\text { Pseudopolyarthritis: K, S } \\
\text { Pseudogout: A } \\
\text { Febrile acute neck pain } \\
\text { Degenerative arthropathy: K, H } \\
\text { Febrile acute neck pain } \\
\text { Degenerative arthropathy: K, H } \\
\text { Degenerative arthropathy: K } \\
\text { Degenerative arthropathy: K } \\
\text { Pseudopolyarthritis: K, W, A } \\
\text { Degenerative arthropathy: K }\end{array}$ & $\begin{array}{l}\text { No } \\
\text { No } \\
\text { No } \\
\text { No } \\
\text { No } \\
\text { No } \\
\text { No } \\
\text { Yes, one year earlier } \\
\text { No } \\
\text { Yes, one week earlier } \\
\text { Yes, one month earlier } \\
\text { No } \\
\text { No } \\
\text { Admission motive } \\
\text { No } \\
\text { Admission motive } \\
\text { No } \\
\text { No } \\
\text { No } \\
\text { No } \\
\text { No }\end{array}$ & $\begin{array}{l}\text { No SF } \\
\text { No SF } \\
\text { No SF } \\
\text { Yes: } K \\
\text { No SF } \\
\text { No SF } \\
\text { Yes: } K \\
\text { Yes: } K \\
\text { Yes: } K \\
\text { No SF } \\
\text { Yes: } K \\
\text { Yes: } K \\
\text { No: } S F \\
\text { No SF } \\
\text { Yes: } K \\
\text { No SF } \\
\text { No SF } \\
\text { No SF } \\
\text { No SF } \\
\text { Yes: } \mathbb{W} \\
\text { No SF }\end{array}$ & $\begin{array}{l}2 \mathrm{~K}, 2 \mathrm{H} \\
2 \mathrm{~K}, 2 \mathrm{~W} \\
2 \mathrm{~K}, 2 \mathrm{~W} \\
2 \mathrm{~K}, 2 \mathrm{~W} \\
2 \mathrm{~K}, \mathrm{H} \\
2 \mathrm{~K}, \mathrm{~W} \\
2 \mathrm{~K}, 2 \mathrm{~W} \\
2 \mathrm{~K}, 2 \mathrm{~W} \\
2 \mathrm{~K}, 2 \mathrm{H} \\
2 \mathrm{~K}, \mathrm{~W} \\
2 \mathrm{~K}, 2 \mathrm{~W}, \mathrm{H} \\
2 \mathrm{~K}, 2 \mathrm{H}, 2 \mathrm{~S} \\
2 \mathrm{~K}, 2 \mathrm{~W}, \mathrm{H} \\
2 \mathrm{~K}, \mathrm{~W} \\
\mathrm{~K}, \mathrm{H} \\
2 \mathrm{H}, \mathrm{S} \\
\mathrm{K}, \mathrm{H} \\
2 \mathrm{~K}, 2 \mathrm{~W} \\
\mathrm{~K}, \mathrm{H} \\
2 \mathrm{~K}, 2 \mathrm{~W}, \mathrm{H} \\
2 \mathrm{~K}, \mathrm{H}\end{array}$ & $\begin{array}{l}\text { Thin } \\
\text { Thin, preodontoid } \\
\text { No } \\
\text { Double } \\
\text { No } \\
\text { No } \\
\text { No } \\
\text { Double } \\
\text { No } \\
\text { Double, erosion } \\
\text { Thin, erosion } \\
\text { Thin } \\
\text { Thick, preodontoid } \\
\text { Thick } \\
\text { No } \\
\text { Thin } \\
\text { Double, preodontoid } \\
\text { Thick } \\
\text { Thin } \\
\text { Thick, preodontoid } \\
\text { No }\end{array}$ \\
\hline
\end{tabular}

$\mathrm{F}=$ Female; $\mathrm{M}=$ male; $\mathrm{TLA}=$ transverse ligament of the atlas; $\mathrm{K}=$ knee; $\mathrm{W}=$ wrist $\mathrm{H}=$ hip; $\mathrm{S}=$ shoulder; $\mathrm{A}=$ ankle; $\mathrm{SF}=$ synovial fluid.

†Thin = calcification of the TLA $<1 \mathrm{~mm}$; thick = calcification of the TLA $>1 \mathrm{~mm}$; Preodontoid=associated preodontoid calcification; double $=$ double banded formation of thick calcification of the TLA; erosion = associated erosion of the odontoid process. 
pyrophosphate dihydrate crystals in synovial fluid examined by compensated polarised light microscopy), ${ }^{6}$ and 13 patients had a possible articular chondrocalcinosis with only typical radiological chondrocalcinosis. In 19 patients, articular chondrocalcinosis was revealed by clinical symptoms in peripheral joints: there were 10 patients with a degenerative chronic arthropathy mainly of the knees and the hips, five with a pseudogout profile (an attack of acute arthritis of the knees (three patients), the ankles (one), or the wrists (one)), and four with an acute or subacute pseudopolyarthritis pattern. In two patients, articular chondrocalcinosis was revealed only by an acute attack of neck pain with segmentary stiffness, fever, and an increased erythrocyte sedimentation rate (ESR) (more than $50 \mathrm{~mm} /$ $1 \mathrm{st} h$ ); in one of them a lumbar puncture was performed and the cerebrospinal fluid was normal; in both, characteristic calcification was found in various joints, though they were asymptomatic. In three additional patients, questioning elicited a history of previous acute neck pain, from one week to one year before their admission to hospital.

A control group comprised 21 age and gender matched patients (18 women and three men: mean age 78.8 (SD 6.8) years (range 66-86), admitted to hospital in the rheumatology or the rehabilitation department for sciatica (four patients), polymyalgia rheumatica (two), neurological diseases (five), or rehabilitation after total hip replacement or bone surgery (10 patients). None had a history of articular chondrocalcinosis, and all were without typical radiological chondrocalcinosis of the knees, pelvis, or wrists.

\section{METHODS}

During the course of their hospital stay, each of the 21 patients with articular chondrocalcinosis and the 21 control subjects underwent radiography of the pelvis, both knees, and both wrists. Computed tomography scans of the cervico-occipital hinge were obtained by a Tomoscan 305 (14 patients) or a Tomoscan SR 7000 Philips (28 patients) without any injection of contrast agent, after each subject gave informed consent. Axial sections passing through the plane of $\mathrm{C} 1$ were performed using the following parameters: slice thickness $1.5 \mathrm{~mm}$; contiguous slices; bone algorithm in each case (1600 Hounsfield units (HU)), complemented by an algorithm more adapted to soft tissues $(800 \mathrm{HU})$.

\section{Results}

Systematic axial computed tomography of the cervico-occipital hinge revealed calcification of the TLA in 14 of 21 patients $(66 \%)$ in the articular chondrocalcinosis group and in none of 21 patients $(0 \%)$ in the control group, demonstrating a statistical relation between articular chondrocalcinosis and calcification of the TLA ( $p<0.001$ between groups; $\chi^{2}$ test). The calcification was present in all five patients with evidence of present or past acute neck pain, but was also revealed by our routine computed tomography scans in another nine asymptomatic patients (table).

There were various features common to the patterns of calcification of the TLA revealed in these patients with articular chondrocalcinosis: the calcification was localised behind the odontoid process, from which it was separated by a hypodense area corresponding to the syndesmo-odontoid joint; it was curvilinear in shape, with an anterior concavity; and it was inserted at each end on the osseous tubercles of the lateral masses of $\mathrm{C} 1$. However, there were differences among patients in the depth of the calcification (from 1.5 to $9 \mathrm{~mm}$ ), and in its appearance: thin and curvilinear (six patients), thick ( $>1 \mathrm{~mm}$ ) and forming a single band (four patients) (figure), or thick and forming a double band (four patients) (figure). Some other abnormalities were noted in association with the appearance in the first six patients: lateral erosions of the odontoid
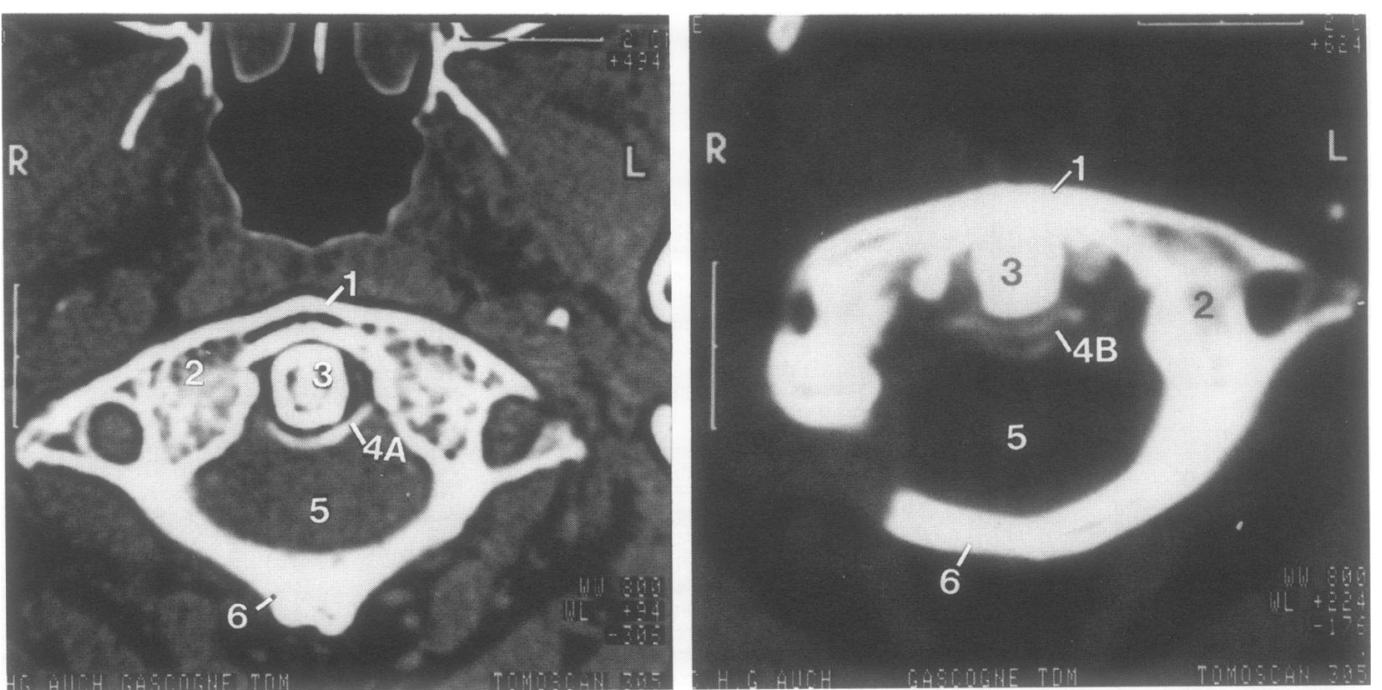

Axial computed tomography slices through the plane of $C 1.1=$ Anterior arch of $C 1 ; 2=$ lateral mass of C1; $3=$ odontoid process; $4 A$ (left) and $4 B$ (right) = single and double band formations, respectively, of the thick calcification of the transverse ligament of the atlas; $5=$ spinal canal; $6=$ posterior arch of $C 1$. 
process in two patients, and preodontoid calcification that may have corresponded to crystal deposits in the atlantoaxial joint in four.

\section{Discussion}

Cervical manifestations of articular chondrocalcinosis include acute attacks of neck pain with segmentary stiffness, fever, and increased ESR, simulating meningitis without any abnormality of the cerebrospinal fluid; such a syndrome may be indicative of articular chondrocalcinosis in the elderly. ${ }^{1-3}$ Moreover, there have been reports of several cases of cervical myelopathies with calcification of the TLA $^{4}$ or the ligamentum flavum ${ }^{7}$ as a result of deposits of calcium pyrophosphate dihydrate crystals compressing the spinal cord. In the course of postmortem examinations, crystal accumulation has been described at other sites in the cervical spine: intervertebral discs, interspinous bursae, apophyseal joints, and the atlantoaxial joint. ${ }^{8}$ In articular chondrocalcinosis, plain radiographs of the cervical spine may show calcification of the intervertebral discs $^{2}$ or the atlantoaxial joint, ${ }^{89}$ destructive discopathies, ${ }^{1}$ or atlantoaxial subluxations. ${ }^{4}$ Dirheimer et al made systematic radiotomographic examinations of the cervicooccipital region in 27 patients (mean age 73 years) with articular chondrocalcinosis who did not complain of pain in the cervical spine; they found calcification of the syndesmo-odontoid region in $12(44 \%)$, with linear, homogeneous, continuous, concave calcification located posterior to the posterior aspect of the odontoid process in five patients, probably affecting the TLA. ${ }^{10}$

Only computed tomography examination of the cervico-occipital hinge can reveal the sites of this calcification with precision. Previous computed tomography studies in healthy people described the appearance of the normal TLA seen on axial and sagittal sections as a thick (1-2 $\mathrm{mm}$ ) and regular band, concave forward around the posterior aspect of the dens, hyperdense, and separated from adjacent planes by hypodense areas: the fatty sliding cellular plane towards the back, and the syndesmo-odontoid joint towards the front. ${ }^{11} 12$ In articular chondrocalcinosis, calcification ot the TLA revealed by computed tomography has been reported in a 79 year old asymptomatic woman, ${ }^{5}$ in three elderly patients with acute neck pain, ${ }^{3}$ and in an 84 year old woman with compression of the spinal cord. ${ }^{4}$

We found calcification in 14 patients that was of three main types on computed tomography: thin $(<1 \mathrm{~mm})$ and curvilinear, thick $(>1 \mathrm{~mm})$ in a single band, and thick $(>1$ $\mathrm{mm}$ ) in a double band. To our knowledge, this double banded appearance has previously been reported from computed tomography in only one patient; ${ }^{12}$ it could reflect the juxtaposition of two calcified lines in the syndesmo-odontoid joint and in the TLA, or the heterogeneity of deposits in the TLA producing either a single or a double band according to the level at which the slices were taken.

The reason why calcium pyrophosphate dihydrate crystal deposits are found in the TLA in articular chondrocalcinosis may be explained on the basis of a structural analogy with the menisci of the knees: the TLA may be considered to be fibrocartilaginous because of the presence of chondroid cells. ${ }^{13}$ However, calcification of the TLA has also been found in other diseases such as rheumatoid arthritis ${ }^{14}$ or acromegaly, ${ }^{14}$ and should be distinguished from calcification localised at the top of the dens and composed of apatite deposits typical of the crowned dens syndrome. ${ }^{15}$

In conclusion, routine axial computed tomography of the cervico-occipital hinge showed calcification of the transverse ligament of the atlas in $66 \%$ of our patients with articular chondrocalcinosis, compared with none of our control patients, thus establishing a relationship between such calcification and articular chondrocalcinosis $(p<0.001)$. Although this calcification often remains asymptomatic, it can be associated with attacks of acute neck pain with segmentary stiffness, fever, and increased ESR, in some cases indicating the presence of articular chondrocalcinosis.

1 Benoist M, Bloch-Michel H, Kahn M F, Polack Y. Les manifestations vertébrales de la chondrocalcinose articulaire. A propos de 80 observations. Rev Rhum 1980; 47: $337-43$.

2 Le Goff P, Pennec Y, Schwarzberg C. Cervicalgies aiguës fébriles simulant un syndrome méningé révélatrices de la chondrocalcinose articulaire. Rev Rhum 1980; 47: 507-9.

3 Weber M, Gerber H. Akutes zervikalsyndrom bei chondrocalcinose. Drei altere patienten mit verkalkungen des ligamentum transversum atlantis. Schweiz Med des ligamentum transversum

4 Ciricillo S F, Weinstein P R. Foramen magnum syndrome from pseudo-gout of the atlanto-occipital ligament. f Neurosurg 1989; 71: 141-3.

5 Dirheimer Y, Wackenheim C, Dietemann J L. Calcifications of the transverse ligament in calcium dihydrate deposition disease. Neuroradiology 1985; 27: 87

6 McCarty D J. Calcium pyrophosphate dihydrate crystal deposition disease (pseudo-gout syndrome). Clinical aspects. Clin Rheum Dis 1977; 3: 61-9.

7 Ellman M H, Vazquez T, Ferguson L, Mandel N. Calcium pyrophosphate deposition in ligamentum flavum. Arthritis Rheum 1978; 21: 611-3.

8 Resnick D, Pineda C. Vertebral involvement in calcium pyrophosphate dihydrate crystal deposition disease. pyrophosphate dihydrate
Radiology $1984 ;$ 153: 55-60.

9 Laval-Jeantet $M$, Scala $H$. Chondrocalcinose articulaire diffuse. F Radiol Electrol 1963; 44: 793-6.

10 Dirheimer Y, Bensimon C, Christmann D, Wackenheim C. Syndesmo-odontoid joint and calcium pyrophosphate dihydrate deposition disease. Neuroradiology 1983; 25: 319-21.

11 Daniels D L, Williams A L, Haughton V M. Computed tomography of the articulations and ligaments at the occipito-atlanto-axial region. Radiology 1983; 146: 709-16.

12 Burguet J L, Sick H, Dirheimer Y, Wackenheim A. CT of the main ligaments of the cervico-occipital hinge. the main ligaments of the

13 Sick H. L'adaptation des tendons à la réflexion. Arch Anat Histol Embryol 1964; 47: 370-446.

14 Castor W R, Miller J D R, Russel A S, Chiu P L, Grace M, Hanson J. Computed tomography of the cranio cervical junction in rheumatoid arthritis. F Comput Assist Tomogr 1983; 7: 31-6.

15 Alcalay M, Ferrié N, Vandermarcq P, Le Goff P, Le Parc J P, Bontoux D. Syndrome de l'odontoïde couronné. A propos de 4 cas. In: Gaucher A, Netter P, Pourcel J, Regent D, eds. Actualités en physiologie et pharmacologie articulaires. Paris: Masson, 1991; 99-106. 